\title{
DETEKSI Blastocystis Spp PADA TINJA ANAK PENDERITA DIARE DENGAN MENGGUNAKAN METODE COPRO ELISA
}

\author{
${ }^{1}$ Ni Wayan Parmini. \\ ${ }^{2}$ Janno B. B. Bernadus \\ ${ }^{3}$ Angle M. H. Sorisi \\ ${ }^{1}$ Kandidat Skripsi Fakultas Kedokteran Universitas Sam Ratulangi Manado \\ ${ }^{2}$ Bagian Parasitologi Fakultas Kedokteran Universitas Sam Ratulangi Manado \\ Email: wayanparmini@ymail.com
}

\begin{abstract}
Diarrhea is one of the main cause of infant mortality in developing countries. Blastocystis spp can cause acute infection as well as manifest as chronic diarrhea in infants due to damaged intestinal mucosa. This study aimed to detect Blastocystis spp in the feces of children with diarrhea. This was a descriptive study with a cross-sectional design. Population consisted of all feces of children suffering from diarrhea. There were 33 samples in this study examined with the copro Elisa test. The results showed that of the 33 samples there were $60.6 \%$ of negative criteria and $39.4 \%$ of positive criteria. The highest percentage age group with diarrhea was $\leq 1$ year of age (48.5\%), while the lowest one was age group of 5-9 years (9.1\%). Male sex was the dominant one. Conclusion: Most of the faeces of children with diarrhea belonged to the negative criteria tested with Copro Elisa.
\end{abstract}

Keywords: Blastocystis Spp, children, diarrhea

\begin{abstract}
Abstrak: Diare merupakan salah satu penyebab utama kematian balita di negara berkembang. Blastocystis spp dapat menyebabkan infeksi akut dan dapat bermanifestasi menjadi diare kronik pada balita akibat rusaknya mukosa usus dan malabsorbsi. Penelitian ini bertujuan untuk mendeteksi Blastocystis spp pada tinja anak penderita diare. Jenis penelitian ini deskriptif dengan desain potong lintang. Populasi penelitian ialah semua tinja anak yang menderita diare. Jumlah sampel diperoleh sebanyak 33 buah dan dilakukan pemeriksaan Copro Elisa. Hasil pemeriksaan dengan Copro Elisa memperlihatkan dari 33 sampel diperoleh kriteria negatif $60,6 \%$ dan kriteria positif 39,4\%. Kelompok usia yang terbanyak menderita diare ialah usia $\leq 1$ tahun (48,5\%), sedangkan yang terendah pada usia 5-9 tahun (9,1\%). Untuk jenis kelamin didapatkan jenis kelamin laki-laki 60,6\%, dan jenis kelamin perempuan 39,4\%. Simpulan: Sebagian besar tinja anak yang menderita diare termasuk kriteria negative dengan pemeriksaan Copro Elisa.
\end{abstract}

Kata kunci: Blastocystis spp, anak, diare

Diare merupakan salah satu penyebab utama kematian balita di negara berkembang. Angka kejadian diare pada anak tiap tahun diperkirakan 2,5 milyar, dan lebih dari setengahnya terdapat di Afrika dan Asia Selatan. Secara global setiap tahun penyakit ini menyebabkan kematian balita sebesar 1,6 juta. ${ }^{1}$

Di Indonesia, hampir 69 juta orang tidak memiliki akses terhadap fasilitas sanitasi dasar dan 55 juta orang tidak memiliki akses terhadap sumber air yang aman. Air mempunyai peran yang penting dalam kehidupan manusia, tetapi air juga dapat merupakan media penularan penyakit. $^{1}$

Di Propinsi Sulawesi Utara penyakit diare sampai saat ini masih menjadi 
masalah kesehatan masyarakat, walaupun secara umum angka kesakitan masih berfluktuasi.Sepanjang tahun 2010, kasus diare terlaporkan lebih banyak diwilayah Kabupaten Minahasa yaitu 3.650 kasus dengan 1.492 diantaranya adalah balita. Dari data yang diperoleh di Rumah Sakit Umum Pusat Prof. Dr. Kandou pada tahun 2010-2014. ${ }^{2}$

Diare yang disebabkan oleh kuman patogen penularannya bersifat oro-fecal. Faktor resiko penyebaran penyakit ini adalah sarana pembuangan tinja yang tidak memenuhi syarat dan proses pencucian tangan yang tidak baik setelah buang air besar dan kontak dengan tinja sebelu mengolah makanan. Faktor resiko lainnya adalah makanan yang tidak higienik, tempat penyimpanan makanan dingin yang kurang dan mengkonsumsi air minum yang tercemar. Beberapa resiko dari penderita adalah usia, kebersihan perorangan dan salah satu penyebab anak terkena penyakit diare karena adanya infeksi Blastocystis spp. Blastocystis spp merupakan salah protozoa usus yang cukup sering ditemukan pada manusia. Blastocystis spp tersebar kosmopolit dan merupakan parasit yang sering ditemukan pada studi-studi epidemiologi; oleh karena itu penyakit diare masih perlu mendapatkan perhatian khusus dalam penanganannya. ${ }^{1}$

Blastocystis spp dapat menyebabkan infeksi akut dan dapat bermanifestasi menjadi diare kronik pada balita akibat rusaknya mukosa usus dan malabsorbsi. Karena kesulitan mendeteksi Blastocystis spp di laboratorium umum (selain parasit) dan pemeriksaan mikroskopik memiliki ambang batas maka diperlukan pemeriksaan Copro Elisa untuk mendeteksi Blastocystis spp pada tinja.

\section{METODE PENELITIAN}

Jenis penelitian yang digunakan ialah deskriptif dengan pendekatan potong lintang. Tempat penelitian dilakukan di RSU Wolter Mongisidi Manado dan Laboratorium Parasitologi Klinik Fakultas Kedokteran Universitas Sam Ratulangi
Manado. Populasi penelitian ialah semua tinja anak yang menderita diare.

\section{HASIL PENELITIAN}

Sampel pada penelitian ini 33 tinja anak yang menderita diare. Pada Tabel 1 dapat dilihat kelompok usia yang terbanyak menderita diare ialah usia $\leq 1$ tahun (48,5\%), sedangkan yang terendah pada kelompok usia 5-9 tahun (9,1\%).

Tabel 1. Distribusi Frekuensi Berdasarkan Usia

\begin{tabular}{ccc}
\hline Usia & $\mathrm{N}$ & $\%$ \\
\hline$\leq 1$ tahun & 16 & 48,5 \\
1,1-3 tahun & 9 & 27,3 \\
3.1-5 tahun & 5 & 15,2 \\
5-9 tahun & 3 & 9,1 \\
Total & 33 & 100 \\
\hline
\end{tabular}

Pada Tabel 2 didapatkan hasil bahwa karakteristik sebaran jenis kelamin sampel penelitian sebagian besar berjenis kelamin laki-laki (60,6\%).

Tabel 2. Distribusi Frekuensi Berdasarkan Jenis Kelamin

\begin{tabular}{ccc}
\hline Jenis Kelamin & $\mathrm{n}$ & $\%$ \\
\hline Laki-laki & 20 & 60,6 \\
Perempuan & 13 & 39,4 \\
Total & 33 & 100 \\
\hline
\end{tabular}

Pada Tabel 3 terlihat karakteristik sebaran kriteria hasil pemeriksaan Copro Elisa. Sebagian besar termasuk dalam kriteria negatif yaitu $60,6 \%$ sedangkan kriteria positif sebesar 39,4\%.

Tabel 3. Distribusi Frekuensi Berdasarkan Hasil Pemeriksaan Copro Elisa

\begin{tabular}{ccc}
\hline $\begin{array}{c}\text { Kriteria Hasil } \\
\text { Pemeriksaan }\end{array}$ & N & $\%$ \\
\hline Positif & 13 & 39,4 \\
Negatif & 20 & 60,6 \\
\hline Total & 33 & 100 \\
\hline
\end{tabular}

\section{BAHASAN}

Pada penelitian ini terdapat 33 sampel tinja dari anak yang menderita diare. 
Karakteristik usia yaitu lebih banyak terdeteksi Blastocystis spp pada anak umur $\leq 1$ tahun $(48,5 \%)$, dengan hasil positif 5 sampel (15,2\%). Pada usia $\leq 1$ tahun ketergantungan masih sangat tinggi kepada orang tua dari segi kebutuhan bahkan kebersihan diri, sehingga bila orang tuanya tidak memperhatikan, maka kecenderungan anak menderita diare cukup tinggi. Hasil penelitian ini tidak sejalan dengan penelitian yang dilakukan di Baghdad Iraq yaitu kelompok umur yang paling banyak terdeteksi Blastocystis spp yaitu umur 5-10 tahun. ${ }^{3}$

Berdasarkan jenis kelamin diperoleh data sebagian besar pemeriksaan Copro Elisa pasien diare ialah berjenis kelamin laki-laki (60,6\%) dibandingkan dengan jenis kelamin perempuan (39,4\%). Hasil penelitian ini berbeda dengan penelitian Cesar di Brazil tahun 2008 dimana dari 23 sampel positif Blastocyistis spp terdapat 15 pada perempuan dan 8 pada laki laki. ${ }^{4}$

Pemeriksaan mengunakan Copro Elisa ini sendiri memiliki beberapa keuntungan, yaitu: lebih akurat, dianggap sangat sensitif, spesifik dan menguntungkan dibandingkan dengan metode lain yang digunakan untuk mendeteksi zat dalam tubuh, seperti uji radioimun (RIA), ${ }^{5}$ serta kemampuan mendeteksi antigen Blastocystis spp tidak dipengaruhi oleh batas ambang penglihatan

Berdasarkan hasil penelitian mengunakan Copro Elisa (Tabel 3), dari 33 sampel didapatkan hasil positif sebanyak 13 sampel (39,4\%) dan hasil negatif sebanyak 20 sampel (60,6\%). Kurangnya hasil positif yang ditemukan sesuai dengan insiden diare akibat Blastocystis spp di RSUP Prof. Dr Kandou pada tahun 2010 2014 yaitu hanya sebesar 2,8\%. Selain itu pemeriksaan mengunakan Copro Elisa ini mengunakan antibodi poliklonal dimana tingkat sensitifitasnya masih lebih rendah dibandingkan yang menggunakan antibodi monoklonal.

Penelitian sebelumnya yang dilakukan oleh Nofita et al. ${ }^{6}$ mengunakan pemeriksaan mikroskopis langsung yang memiliki banyak keterbatasan. Hal ini antara lain di sebabkan oleh morfologi Blastocystis dan penyebarannya di feses masih belum jelas. Bentuk kista Blastocystis sangat sulit diidentifikasi sehingga mungkin luput pada pemeriksaan mikroskopik secara langsung.

Penelitian sebelumnya yang dilakukan di Rumah Sakit Anak Pittsburgh USA, tentang insiden dan karakteristik Blastocystis spp pada anak dengan mengunakan pemeriksaan mikroskopik menunjukkan hasil yang berbeda. Insiden Blastocystis dalam tinja dan ciri klinis infeksi Blastocystis terjadi pada anak-anak, ditemukan 1.736 pasien yang menjalani pemeriksaan tinja Blastocystis. Sebanyak 75\% pasien terpapar dengan air sumur yang ada di negara-negara berkembang. Sebanyak 85\% pasien mengalami gejala gastrointestinal, seperti sakit perut, diare, muntah dan penurunan berat badan. Blastocystis merupakan satu-satunya parasit yang ditemukan pada 35 dari 39 anak dengan gejala gastrointestinal. Hasil penelitian menunjukkan bahwa anak-anak yang terinfeksi Blastocystis sering mengalami gejala gastrointestinal. ${ }^{7}$

Perbedaan hasil dalam penelitian ini mungkin diakibatkan karena keterbatasan waktu penelitian dan adanya faktor -faktor lain yang mungkin berperan hingga di dapatkan sedikit hasil yang positif. Faktor faktor tersebut dapat berasal baik pada pasien sendiri atau dari keluarga. Faktor lain yang menyebabkan diare yaitu: Rotavirus, Escheria coli, Shighella, Campylobacter jejuni, Vibrio cholerae, Salmonella sp (non tifoid), Yersinia sp, Vibrio para haemolyticus, Giardia lamblia, Entamoeba histolytica, dan Cyptosporodium, sedangkan yang nonmikroba ialah makanan, alergen, dan malnutrisi. $^{8}$

\section{SIMPULAN}

Berdasarkan hasil penelitian dapat disimpulkan bahwa dengan pemeriksaan Copro Elisa sebagian besar tinja anak yang menderita diare termasuk kriteria negatif Usia penderita anak yang terdeteksi Blastocystis spp terbanyak pada usia $\leq 1$. 
Jenis kelamin yang terbanyak terdeteksi Blastocystis spp ialah laki-laki.

\section{SARAN}

Disarankan untuk mengadakan penyuluhan dan bimbingan hidup bersih dan sehat sesering mungkin kepada orang tua.

Diperlukan adanya koordinasi dengan instansi kesehatan dalam memberikan penyuluhan-penyuluhan tentang pencegahan dan penanggulangan wabah diare di masyarakat.

Disarankan untuk melakukan penelitian yang bersifat analitik untuk mengetahui faktor-faktor penyebab diare pada anak.

\section{DAFTAR PUSTAKA}

1. Mulyani SN. Faktor resiko diare akut pada balita di Bagian Ilmu Kesehatan Anak RSUP Dr. Sardijto,Yogyakarta. Berita kedokteran masyarakat.Vol $27: 10$

2. Profil diare provensi Sulawesi Utara 2010

3. Badtarva E, Founia Y. Prevalence of blastocystis hominis in Lorestan province west of Iran 2010. Asian jbiol sci. 2012;5(1):57-61.

4. Ndeshaw ET, Gemuchu $T$, Beyene $P$. Significance of blastocystis hominis in patients referred for bacteriological stool culture at EHURI. Specimens were brought to bacteriology laboratory. Enhiop J health. 2007;21.

5. Sino Biological inc. [cited 2015 Jan 13]. Available from: http:/ www.elisantibody.comdiseases. Gajah Mada 2005

6. Nofita E, Harminarti N, Rusjdi RS. Identifikasi blastocystis hominis secara mikroskopis dan PCR pada sampel feses di laboratorium RSUP. Dr. M. Djail Padang. MKA. 2014;37:27.

7. O’Gorman MA. Prevalence and characteristics of Blastocystis horninis infection in children. Clinical Pediatrics, Sage Journals, October 2008.

8. Amaliah S. Hubugan sanitasi lingkungan dan faktor budaya dengan kejadian diare pada anak balita di desa Toryo kecamatan Bondosari kabupaten Sukoharjo. Prosidang seminar nasional UNIMUS 2010:92. 